\title{
IDEALISME EKALAWYA DALAM WIRACARITA MAHABHARATA DAN REFLEKSI PENDIDIKAN DI ERA TATANAN BARU
}

\author{
I Made Arsa Wiguna \\ Universitas Hindu Negeri I Gusti Bagus Sugriwa Denpasar \\ imadearsawiguna@gmail.com
}

\begin{abstract}
This paper aims to interpret the learning idealism of the Ekalawya figure in the Mahabharata and translate it as a reflection of the learning process in this era of the new order. The problematization between regulations and the real conditions of students has given implications for the implementation of online learning. There are many obstacles that arise, ranging from limited infrastructure, costs required and mastery of ICT, both from the teacher and student side. Refers to literary reception theory and hermeneutic methods, Ekalawya is a true disciple, his ideals such as unyielding, independence, discipline, teacher devotion, and making his yad as an obligation have led him to become a great archer. His learning experiences, such as; independent learning, obedience to the social rules of Catur Varna, respect for Drona as a teacher, and also the sincere offerings (daksina) in the form of his thumb. The limited interaction between teachers and students, hard work in doing assignments, independence and honesty of students in answering the evaluation questions, and respect that is maintained are a form of reflection on the learning experiences of Ekalawya in the era of the new order.
\end{abstract}

Keyword: Idealism, Ekalawya, Mahabharata, Reflection, Education, New Order

\begin{abstract}
Abstrak
Tulisan ini bertujuan untuk menginterpretasikan idealisme tokoh Ekalawya dalam Mahabharata dan menterjemahkannya sebagai bentuk refleksi pendidikan di era tatanan baru. Pergulatan antara regulasi dan kondisi riil siswa berimplikasi pada pelaksanaan pembelajaran secara daring. Tidak sedikit kendala yang muncul, mulai dari keterbatasan sarana prasarana, biaya yang dibutuhkan serta penguasaan TIK, baik dari sisi guru maupun siswa. Mengacu pada teori resepsi sastra dan metode hermeneutika, idealisme Ekalawya yang ditemukan dalam Adiparva Mahabharata memuat nilai moral edukatif. Ekalawya adalah sosok murid sejati, idealismenya seperti pantang menyerah, mandiri, disiplin, guru bhakti, dan menjadikan yadnya sebagai kewajiban telah mengantarkannya sebagai seorang pemanah yang hebat. Refleksinya pada pendidikan saat ini berkaitan dengan keterbatasan Ekalawya di jamannya, kemandirian dalam belajar, kepatuhan pada aturan Catur Varna, rasa hormat kepada guru Drona, hingga persembahan (daksina) berupa ibu jarinya. Keterbatasan interaksi guru dan siswa, kerja keras dalam mengerjakan tugas, kemandirian dan kejujuran peserta didik dalam menjawab soal evaluasi, serta rasa hormat yang tetap dijaga merupakan bentuk refleksi pengalaman belajar Ekalawya di era tatanan baru.
\end{abstract}

Kata Kunci: Idealisme, Ekalawya, Mahabharata, Refleksi, Pendidikan, Tatanan Baru 


\section{Pendahuluan}

Tahun 2020 menjadi momen penting bagi hampir seluruh negara di belahan dunia, karena telah terjadi perubahan besar pada berbagai elemen di dalamnya. Di Indonesia sendiri, pandemi covid-19 mulai mewabah sejak Maret tahun 2020, dan menyebar ke seluruh wilayah nusantara. Jumlah pasien terinfeksi covid-19 kian hari semakin bertambah. Efek domino dari pandemi ini, selain pada kesehatan, juga berdampak pada masalah-masalah lainnya, termasuk pada ranah pendidikan. Kebijakan yang diambil oleh pemerintah pun harus mempertimbangkan berbagai kemungkinan dan resiko yang akan terjadi. Pada bidang pendidikan, sebagian besar pemerintah di negara-negara terdampak menerapkan sistem pembelajaran daring, termasuk di Indonesia sendiri menerapkan hal yang sama yakni belajar dari rumah.

Kebijakan pelaksanaan pembelajaran dari rumah melalui media digital atau yang dikenal dengan terminologi daring (dalam jaringan) dirancang agar peserta didik terhindar dari bahaya penyebaran covid-19. Guru atau pendidik tetap melaksanakan tugas utamanya mendidik dan mengajar namun dengan format yang berbeda. Setiap satuan pendidikan dan pihak yang terlibat di dalamnya berupaya untuk beradaptasi dengan format pembelajaran daring ini. Untuk sekolah yang sebelumya memang sudah menerapkan blended learning, relatif lebih mudah beradaptasi daripada sekolah yang baru memulai menggunakan format pembelajaran daring ini. Guru dituntut tidak hanya mampu menguasai penggunaan teknologi dan informasi, namun juga harus kreatif dan inovatif dalam membangun suasana pembelajaran daring yang efektif, sekaligus membangun keaktifan siswa (active learning).

Setiap perubahan tentu akan diikuti oleh konsekuensi, demikian pula dengan penerapan pembelajaran daring, beragam kendala kemudian muncul, baik dari sisi pendidik, peserta didik maupun orangtua. Siswa yang mengikuti pembelajaran dari rumah biasanya didampingi oleh orangtua, namun jika orangtuanya memiliki kesibukan dan tidak bisa ditinggalkan, maka siswa belajar hanya dipandu secara daring dalam waktu yang relatif singkat oleh guru melalui platform digital yang digunakan. Sementara keterbatasan lain muncul dari siswa yang tidak memiliki perangkat yang mendukung pembelajaran daring ini seperti smartphone maupun laptop. Kenyataan bahwa pembelajaran daring ini memerlukan biaya berupa kuota internet tidak bisa disangkal, begitupun ketika orangtua siswa memiliki keterbatasan secara finansial, terlebih yang memang terbatas sejak awal atau karena pemutusan hubungan kerja dari perusahaannya akibat pandemi ini, maka ini menjadi masalah lainnya. Tidak hanya kemampuan untuk beradaptasi dengan pembelajaran daring ini saja yang dibutukan, tetapi kesiapan mental serta kegigihan siswa dalam mengerjakan tugas maupun latihan yang diberikan oleh guru. Belajar dari rumah hendakanya tidak dimanfaatkan atau disamakan dengan liburan, tapi belajar seperti layaknya pra pandemi namun dalam format yang berbeda.

Pendidikan diarahkan untuk membentuk karakter peserta didik, dan melalui tranformasi pembelajaran era tatanan baru ini, penguatan karakter dapat dioptimalkan. Kedisiplinan, kejujuran, kerja keras, kegigihan, pantang menyerah, rasa ingin tahu, mandiri, kreativitas secara implisit dikuatkan melalui pembelajaran daring ini. Walaupun guru dan peserta didik tidak bertatap muka langsung (meskipun ada beberapa sekolah yang menggunakan media digital berupa video conference), namun peserta didik hendaknya memiliki kemauan yang kuat untuk menuntut ilmu. Seperti halnya sosok siswa ideal yang tergambar pada tokoh Ekalawya dalam wiracarita Mahabharata. Kisahnya merefleksikan pendidikan di era tatanan baru, ketika interaksi guru dan siswa menjadi sangat terbatas, begitu juga dengan keterbatasan yang ada pada diri siswa, namun Ekalawya tidak pernah kehilangan semangat dalam menuntut ilmu. Walaupun kisah ini sudah muncul berabad-abad yang lalu, namun pesan-pesan yang disampaikan masih sangat relevan hingga kini. Beberapa artikel yang mengulas tentang Ekalawya diantaranya Suprapti (2020) mengenai penumbuhkembangan kemandirian siswa dengan spirit Ekalawya. Tulisan ini hanya menekankan pada aspek kemandirian siswa yang dikorelasikan dengan spirit Ekalawya, sehingga belum menyentuh idealisme Ekalawya secara 
menyeluruh. Selanjutnya Juliani (2020) dalam tulisannya mengulas tentang sistem belajar otodidak Ekalawya yang memiliki kedekatan juga dengan ulasan Suprapti yakni kemandirian, hanya saja Juliani menambahkan sudut pandang pendidikian agama Hindu, seperti bakti, etika, semangat dan religius. Namun, tulisan Juliani masih belum secara optimal menunjukkan suatu pendekatan pendidikan Hindu, dan ulasannya masih sangat minim dari keterkaitan dengan sloka-sloka dalam susastra Hindu. Selain itu tulisan Juliani tidak dikorelasikan dengan konteks pembelajaran siswa di era tatanan baru saat ini. Selanjutnya ada pula tulisan Tangkas (2020) yang menekankan pada keberhasilan mutu pendidikan yang ditunjukkan oleh Ekalawya. Pada tulisan tersebut, fokusnya adalah pada hubungan antara guru dan siswa serta kemandirian dan keseriusan siswa dalam menuntut ilmu sehingga menghasilkan output pendidikan yang bermutu, namun dalam tulisan Tangkas tidak mebicarakan tentang idealisme Ekalawya secara mendalam yang juga merupakan kunci keberhasilannya seperti kedisiplinan dan pantang menyerah. Tulisan tersebut juga tidak dalam konteks refleksi pendidikan di masa pandemi seperti yang dialami siswa saat ini. Oleh sebab itu, tulisan ini akan mengkaji lebih mendalam tentang idealisme Ekalawya dan refleksinya bagi pendidikan di era tatanan baru.

\section{Metode}

Penelitian ini menggunakan paradigma kualitatif mengingat analisis yang dilakukan menggunakan sumber pokok yakni teks Adiparva Mahabharata. Ketajaman analisa diutamakan menggunakan analisis interpretatif dengan pendekatan hermeneutik. Metode yang digunakan untuk menyusun inferensi yang valid dari teks terkait kisah Ekalawya mengacu pada metode analisis isi (content analysis) kualitatif dengan pendekatan hermeneutika. Mengutip pernyataan Riceour (2006: 57) hermeneutika adalah teori mengenai pemahaman yang baik dalam menafsirkan teks, yakni teks Ekalawya. Sejalan dengan itu, Ahmad (2018: 13) menyatakan bahwa yang dimaksud pendekatan hermeneutika adalah suatu metode penafsiran meliputi proses analisis bahasa, selanjutnya analisis konteks dan kemudian mengambil makna yang diperoleh dari pemahaman maupun penafsiran terhadap isi teks yang dilakukan. Sumber data primer yang digunakan adalah teks Adiparva Mahabharata, yaitu pada bagian Ekalawya Sang Nisada karya Kamala Subramaniam. Sumber data sekunder diperoleh dari artikel terkait serta buku referensi yang mendukung penelitian. Untuk mendapatkan data maupun bahan dalam penelitian ini, penulis menggunakan teknik membaca teks Ekalawya, mencatat nilainilai idealisme tokoh Ekalawya serta teknik pustaka. Teks cerita tentang Ekalawya yang dipahami, kemudian ditafsirkan, diterjemahkan dan didialogkan dalam hal ini dengan pendidikan era tatanan baru yang mewakili kondisi pendidikan pembelajaran saat ini.

Bersandar pada teori resepsi sastra dengan meminjam pendapat Aritonang (2018: 64) bahwa karya sastra dapat bernilai jika pembaca sebagai penikmat karya sastra memberikan nilai. Kutipan kisah Ekalawya dalam susastra Adiparva Mahabharata ini memuat nilai-nilai moral edukatif yang jika dikaitkan dengan konteks pendidikan di era tatanan baru ini merefleksikan kondisi dan upaya yang harus dilakukan peserta didik menghadapi sistem pembelajaran saat ini.

\section{Hasil Dan Pembahasan}

Pendidikan pada era tatanan baru ini secara progresif sesungguhnya menunjukkan perubahan signifikan dari model dan metode pembelajaran konvensional menuju active learning berbasis teknologi informasi. Pandemi Covid 19 ini otomatis mengimplikasi pada perubahan tersebut. Integrasi TIK dalam pembelajaran nampaknya mulai mewujudkan diri secara tidak langsung melalui format pembelajaran daring ini. Jika dikorelasikan dengan bentuk-bentuk belajar menurut A.De Block (Riyanto, 2012: 47) maka secara implisit, belajar dengan format daring ini dapat dikategorikan ke dalam bentuk belajar yang tidak begitu disadari, tergolong belajar (secara tersembunyi). Walaupun siswa tidak menyadari hal ini, tetapi ada nilai-nilai karakter yang dibangun dan dikuatkan. 
Pendidikan merupakan refleksi dari kebudayaan, sehingga dalam pendidikan ada transmisi kebudayaan yang bertujuan menyempurnakan segala kecakapan peserta didik dalam menghadapi persoalan-persoalan hidup serta harapan-harapan kebudayaan (Titib, 2002:13). Pendidikan menjadi hal penting bagi setiap insan yang terlahir, karena dengan pendidikan akan menunjukkan kualitas manusia seutuhnya, mampu menggunakan akal pikiran untuk kesejahteraan dirinya dan lingkungannya serta berkepribadian yang mulia/luhur. Hal ini salah satunya bisa diwujudkan melalui pendalaman ajaran agama, dan dalam agama Hindu pendidikan mendapat perhatian khusus untuk mewujudkan karakter generasi muda yang suputra (berakhlak mulia, berbudi pekerti luhur). Berkaitan dengan sistem pendidikan, dalam Hindu sudah diatur tentang empat tahapan hidup sebagai manusia (Catur Asrama), diawali dengan Brahmacari (tahapan menimba ilmu, mengenyam pendidikan), Grhasta (tahapan hidup berumah tangga), Vanaprastha (meninggalkan keterikatan duniawi), dan Bhiksuka/Sanyasin (benar-benar lepas dari belenggu keterikatan duniawi). Pada masa Brahmacari inilah seseorang mengenyam pendidikan secara formal maupun non formal, sehingga pengendalian diri, indria dan penguatan karakter dominan terjadi pada fase ini.

Pada fase Brahmacari ini, seorang sisya (siswa spiritual) tinggal bersama gurunya di ashram yang biasanya berlokasi di hutan, siswa melayani gurunya dengan baik, bhakti kepada guru, sesuai amanat dalam kitab Taittiriya Upanisad I.11.2 (Radhakrishnan, 2008: 417), salah satunya yakni Acarya devo bhava, guru merupakan perwujudan dewata atau Tuhan itu sendiri, dan dalam Hindu dikenal adanya empat guru yang wajib dihormati (Catur Guru) yakni Guru Reka/ Rupaka (orangtua), Guru Pengajian (guru di sekolah), Guru Wisesa (pemerintah), dan Guru Swadhyaya (Tuhan sebagai guru umat manusia). Realisasinya kini, masa Brahmacari adalah masa menuntut ilmu di sekolah-sekolah formal maupun non formal, etika sebagai siswa harus benar-benar dikuatkan, tekun, disiplin, menghormati guru, tidak mengolok-olok guru, dan etika lainya sebagai siswa. Model pembelajaran Hindu sendiri, salah satunya menekankan pada prilaku yang baik dan fokus pada pelajaran yang diberikan, selain seperti pendidikan yang diberikan oleh Bhagawan Domya dan Bhagawan Drona dalam Adiparwa Mahabharata (Suarjaya, 2018: 54).

Perihal Brahmacari ini banyak dicontohkan dalam wiracarita, baik Ramayana maupun Mahabharata. Salah satu yang cukup populer adalah kisah Ekalawya yang berasal dari golongan Nisadha (pemburu). Kisahnya termuat dalam Adi parva (bagian pertama wiracarita Mahabharata) yang menceritakan proses pendidikan Pandava dan Korava di ashram Bhagavan Drona yang merupakan putra dari Rsi Bharadwaja. Pada masa itu, latar belakang calon siswa menjadi penting, karena sistem Varna yang ketat. Seorang yang bukan dari Varna (golongan) ksatria tidak diperbolehkan belajar memanah atau mengikuti tradisi-tradisi kaum ksatria. Ekalawya yang merupakan golongan nisadha putra Hiranyadhanu (raja pemburu) suatu ketika ingin berguru kepada Drona, tetapi ditolak dengan alasan dirinya bukan dari golongan ksatria. Penolakan itu justru melecut semangat Ekalawya untuk menguasai ilmu memanah dengan jalan membuat patung menyerupai Drona, dan secara diam-diam mengamati dari kejauhan proses pembelajaran yang dilakukan oleh Drona kepada Pandava dan Korava. Hingga suatu ketika, Arjuna yang menurut Drona adalah pemanah terhebat menyaksikan kehebatan Ekalawya dalam memanah hingga menutupi mulut seeekor anjing buruan milik Arjuna yang menggonggong di depan kediaman Ekalawya. Hal ini dilaporkan kepada Drona, dan untuk memastikan bahwa Arjuna tetap pemanah terhebat, maka Drona menemui Ekalawya dan meminta daksina (persembahan kepada guru karena telah mendapatkan ilmu pengetahuan) berupa ibu jari miliknya. Ekalawya pun dengan penuh bhakti menyerahkan potongan ibu jarinya kepada Drona, tanpa kebencian dan tanpa dendam, Ekalawya adalah murid yang ideal (Subramaniam, 2007:46-47). Idealisme Ekalawya dalam menuntut ilmu memanah adalah cerminan sisyal siswa yang tangguh, dan mampu mengatasi masalah dengan baik. Beberapa bentuk idealisme dari Ekalawya yang dapat diteladani diantaranya sebagai berikut: 


\section{Pantang Menyerah}

Pertama adalah pantang menyerah, walaupun ditolak sebagai murid oleh Drona, semangatnya untuk belajar memanah tidak pernah pudar. Pantang menyerah adalah salah satu indikator dari kerja keras, seperti yang dinyatakan oleh Mustari (2014: 43), bahwa ada kesungguhan yang dilakukan oleh orang tersebut dalam menjalankan tugas, tetap bertahan melaksanakan tugas tersebut walau dalam kesulitan, dan berusaha mencari pemecahan terhadap permasalahan tersebut. Mengutip pendapat Fiteriani (2015: 122) bahwa seorang siswa yang termotivasi secara intrinsik memiliki semangat yang lebih baik dalam mengerjakan tugasnya daripada siswa yang termotivasi secara ekstrinsik. Siswa yang termotivasi secara intrinsik tekun dalam belajar, karena tujuannya belajar adalah untuk menguasai ilmu yang ditekuni, bukan untuk mendapat nilai semata atau sanjungan dari gurunya. Hal inilah yang merupakan salah satu ciri yang nampak pada diri Ekalawya. Dalam salah satu kitab Smrti Agama Hindu yakni Slokantara 8 (Sudharta, 2003: 30) disebutkan sebagai berikut:

Kalingaya, sang sadhu-jana siwa sang wwang uttama-janma, yadyapi dira nirdhana, kasyasiha tuwi, agaweha ta sira salah karya, salah hidep, taha tan mangkana sang wwang uttama-janma, iwa padanira nihan, kadyangga ning sardula, sardula ngaranya macan, tugel jarijinya, pisaningu ika mamangan dukut, nora juga mangkana prawrttinya, apan enget ing pinanganya kaja umanya, mangkan ling ing aji.

Terjemahannya:

Orang yang suci, orang yang berbudi pekerti luhur, walaupun sangat miskin, pantang baginya melakukan pekerjaan haram. Begitu juga seekor harimau, meskipun kakinya dipotong hingga remuk, tidak sekalipun mau memakan rumput. Demikianlah halnya bahwa seorang sadhujanma, yakni orang yang terlahir dalam keluarga baik-baik, meskipun ia miskin, pantang untuk melakukan pekerjaan yang bertentangan dengan agama. Jangankan melakukan, memikirkan yang jahat sekalipun ia tidak mau. Sama halnya dengan harimau, walaupun cakarnya dipotong, mustahil akan menyantap rumput, karena ia tahu makanan yang seharusnya ia santap. Begitulah ajaran dalam kitab suci.

Sudharta (2003: 31) dalam ulasannya menggunakan pandangan Svami Vivekananda tentang kebulatan tekad dalam memegang teguh kebenaran, bahwa apapun hambatannya, kebenaran harus tetap diperjuangkan, jangan menjadi manusia yang pengecut dan palsu akan cita-cita. Pernyataan tersebut dapat mewakili idealisme dari Ekalawya, dengan kebulatan tekadnya belajar memanah, walaupun mengalami penolakan, justru berhasil menjadi seorang pemanah yang hebat, bahkan lebih hebat dari Arjuna yang berguru langsung dengan Drona. Idealisme yang kuat agar bisa menguasai ilmu memanah mendorong semangat pantang menyerah dalam diri Ekalawya

\section{Mandiri}

Ekalawya dalam guratan kisahnya menampilkan kemandirian. Mandiri adalah sikap dan perilaku yang tidak bergantung pada orang lain dan mempergunakan segala tenaga, pikiran, waktu untuk merealisasikan harapan, mimpi, dan cita-cita (https://www.kemdikbud.go.id/main/blog/2017/07/ penguatan-pendidikan-karakter-jadipintu-masuk-pembenahan-pendidikan-nasional). Mengutip pendapat Mustari (2014: 78), mandiri merujuk pada sikap percaya diri yang dimiliki seseorang berkaitan dengan potensi dirinya dalam menghadapi segala macam kondisi. Kemandirian akan membantu seseorang untuk menguasai kehidupannya dan dapat menangani apapun yang dihadapi di dunia ini.

Idealisme Ekalaywa semakin nampak ketika mulai berguru dengan Drona menggunakan media patung yang dibuatnya dengan lumpur. Ekalawya menyimbolkan patung tersebut sebagai sosok Drona yang dikagumi, dengan segenap kekuatan yang ada dalam dirinya, belajar secara otodidak, tanpa bantuan siapapun, hingga berhasil mewujudkan citacitanya menjadi seorang pemanah. Ekalawya mampu menentukan jalan hidupnya dengan 
mengambil keputusan berguru pada Drona, dan penolakan yang membuatnya justru semakin kuat berpegang teguh pada prinsipnya menjadi seorang pemanah. Jika dibandingkan dengan wiracarita terdahulu yakni Ramayana, idealisme seperti ini juga ditunjukkan oleh tokoh Rama ketika diberikan anugrah sebuah tempat di Brahmaloka oleh Rsi Sutiksna. Rama menolak dengan lembut dan berkata bahwa loka (tempat) tersebut seharusnya dicapai atas usahanya sendiri, bukan pemberian dari orang lain. Menjadi mandiri tentu didukung dengan adanya tujuan maupun cita-cita yang ingin diraih.

\section{Disiplin}

Disiplin merupakan suatu bentuk pengendalian diri dan bertanggung jawab atas segala macam aturan. Sejalan dengan itu, menurut Daryanto dan Darmiatun (2013: 50) bahwa perkembangan disiplin dalam diri individu dipengaruhi oleh tiga hal. Pertama, pola asuh dan kontrol dari orangtua, hal ini berpengaruh terhadap cara seorang anak dalam berpikir, berkata dan berprilaku. Berkaitan dengan penguatan nilai disiplin (Lilawati, 2020: 552) menyatakan bahwa orangtua berperan penting dalam hal mengatur jadwal belajar anak ketika berada di rumah termasuk mengulang pelajaran yang diberikan oleh guru. Kedua, pemahaman tentang diri sendiri dan motivasi, karena pemahaman terhadap keberadaan diri sendiri, tentang keinginan positif dalam diri akan mendorong/memotivasi seseorang untuk merencanakan suatu tindakan mencapai visinya tersebut, kemudian secara disiplin mematuhi rencana yang telah dibuat. Ketiga, hubungan sosial serta pengaruhnya pada individu, karena melalui interaksi sosial mengajarkan seseorang untuk patuh pada aturan sosial agar diterima di lingkungan sosial. Dalam kedisiplinan akan dijanjikan sebuah pencapaian yang baik, bahkan melebih dari harapan, walaupun dalam menjalankan disiplin ada beban dan perjuangan, tetapi jika didasari oleh prinsip yang kuat untuk menggapai tujuan, maka penderitaan itu tidak akan membebani, justru kedisiplinan akan berbuah manis.

Idealisme ini kembali ditampilkan oleh Ekalawya yang merupakan putra Hiranyadhanu, raja dari para pemburu. Sebagai putra seorang raja/pemimpin, teladan-teladan dari ayahnya telah membentuk idealisme Ekalawya, salah satunya disiplin dalam mencapai tujuan, disiplin dalam mematuhi aturan. Ekalawya adalah putra dari golongan pemburu, bukan seorang ksatria, dan inilah alasan Drona menolak Ekalawya menjadi muridnya. Pada era Dvapara (jaman ketiga dalam Catur Yuga), aturan tentang varna (penggolongan masyarakat ke dalam tugas dan kewajiban) sangat ketat. Brahmana varna bertugas mempelajari kitab suci dan menyebarluaskan ajaran agama serta memimpin upacara yadnya, golongan ksatria bertugas menjadi pemimpin wilayah, Negara, kerajaan, berperang melindungi wilayahnya dan varna lainnya, golongan waisya tugasnya adalah berdagang, bertani, beternak, berkebun, sedangkan golongan sudra bertugas melayani ketiga golongan tadi.

Pada jaman Weda kuno, Manu hanya menggolongkan masyarakat menjadi Tri Varna (Brahmana, Ksatria, Waisya), namun ketika masuk ke jaman Brahmana, ditambahkan satu golongan lagi yakni sudra hingga menjadi Catur Varna. Adanya aturan demikian, berpengaruh juga pada sistem pendidikan saat itu. Penolakan sebagai murid karena bukan berasal dari ksatria varna tidak hanya menimpa Ekalawya, tetapi juga Karna (Putra Dewa Surya dan Kunti) yang diasuh oleh Atiratha dan Radha. Karna belum mengetahui silsilah orangtuanya yang sebenarnya, yang diketahui hanyalah ayahnya seorang kusir kereta di Hastinapura. Drona juga menolak Karna sebagai muridnya, akibat status sosialnya bukan merupakan golongan ksatria, melainkan seoarang Sutaputra (ayahnya terlahir dari seorang ksatria dan brahmana). Karna akhirnya berguru kepada Parasurama yang membenci ksatria dengan cara berbohong mengaku sebagai keturunan Brahmana.

Baik Ekalawya maupun Karna sama-sama memiliki idealisme dalam dirinya untuk mendapatkan ilmu memanah, tetapi jalan yang diambil berbeda. Ekalawya patuh kepada aturan dan memilih mengalah daripada harus melakukan kesalahan seperti halnya Karna. Kedisiplinan dalam diri Ekalawya juga tampak melalui latihan-latihan yang dilakukan, dengan mengabaikan 
kesenangan-kesenangan yang bisa diperoleh oleh seorang pemuda. Disiplin adalah kunci untuk meraih cita-cita, dan ini adalah pesan yang disampaikan melalui idealisme Ekalawya.

\section{Guru Bhakti}

Seorang siswa sudah sepatutnya untuk bersikap hormat kepada gurunya, tidak membangkang atau menentang, tidak menghina, mengolok-olok bahkan tidak berbohong kepada guru. Konsep Catur Guru dalam ajaran Hindu mendidik umat untuk menghormati keempat guru, yakni Guru Rupaka, Guru Pengajian, Guru Wisesa, dan Guru Swadhyaya. Berkaitan dengan bhakti kepada guru, dalam Sarasamuccaya (Kajeng, dkk, 1997: 179-182) dinyatakan sebagai berikut:

Upadhyayam pitaram mataram ca ye bhidruhyanti manasa karmana va, tesam papam bhrunahtyavicistam nanyastasmat papkrccastiloke.

Terjemahannya:

Seandainya ada orang yang mengkhianati guru, ibu dan bapak, dengan jalan perbuatan, perkataan dan pikiran, orang seperti itu sesungguhnya berdosa besar, bahkan lebih besar daripada bhrunahatya yakni dosa menggugurkan kandungan, jadi sangatlah besar dosanya (Sarasamuccaya 234)

Laukikam vaidikam vapi tathadhyatmikameva ca, yasmaccadhiyeta narastam purvamabhivadayet

Terjemahannya:

Lagi pula orang yang mengajarkan ilmu pengetahuan hukum kemasyarakatan, ilmu pengetahuan berdasarkan Weda (ajaran-ajaran agama), dan ilmu pengetahuan tentang kebatinan serta ilmu pengetahuan lainnya, kepada beliau patut terlebih dahulu memberikan hormat (Sarasamuccaya 236)

Guruna vairanirbandho na kartavyah kadacana, anumanyah prasadyacca guruh pruddho vijanata

Terjemahannya:

Yang patut dilakukan adalah berikut ini yaitu jangan menjawab secara berolok-olok kepada guru, jika beliau gusar, berang hatinya, sabarkan beliau, hiburlah, usahakanlah segala yang menyenangkan beliau (Sarasamuccaya 237)

Samyan mithyapravrtte va vartitavyam guraviha, guruninda nihantyayurmanusyanam na samsayah.

Terjemahannya:

Dan lagi, jangan sekali-kali mencela guru, meskipun keliru perbuatan beliau, hendaklah diusahakan baik-baik cara perlakuan yang layak kepada guru, agar berhasil melaksanakan pengabdian kepada beliau, sangatlah menyebabkan usia pendek serta menimbulkan dosa jika menghina guru (Sarasamuccaya 238)

Sarasamuccaya merupakan saripati dari Mahabharata, dan kitab ini dikatakan sebagai Mahabharatanya orang Indonesia. Tentunya ajaran-ajaran yang termuat di dalamnya tersinspirasi dari sederetan kisah dalam Mahabharata. Jika dicermati kembali sikap dan perilaku Ekalawya identik dengan untaian sloka Sarasamuccaya tersebut, yakni bhakti kepada guru. Ekalawya tidak menaruh dendam sama sekali kepada Drona yang telah menolaknya sebagai murid hanya karena masalah status sosial, tidak ada caci maki yang dilontarkan, begitu besar rasa bhaktinya kepada sang acarya, hingga permintaan daksina dari Drona yang sulitpun dipenuhinya tanpa penolakan. Sebuah persembahan yang berat dan merugikan dirinya, tetapi Ekalawya mengabaikan itu semua hanya demi bhaktinya kepada Drona. Idealismenya bahwa guru adalah perwujudan Tuhan (Acharya devo bhava) benar-benar dipraktikkan. Tidak berlebihan rasanya jika sisya mahottama (siswa yang utama, ideal) layak disematkan pada diri Ekalawya. 


\section{Yadnya Adalah Kewajiban}

Kata yadnya berasal dari bahasa Sanskerta yajna, dari akar kata yaj yang artinya memuja atau memberi penghormatan, menjadikan suci, mempersembahkan, maupun bertindak sebagai perantara. Dari urat kata ini muncul kata yaja (kata-kata dalam pemujaan), yajata (layak memperoleh penghormatan), yajus (sacral, ritus, agama), dan yajna (pemujaan, doa, persembahan). Yadnya diartikan sebagai korban suci atas dasar cinta kasih dan pengabdian (Netra, 2009: 47). Ketulusan adalah syarat utama dalam melaksanakan yadnya, ini yang kemudian disebut satvika yadnya dalam Bhagavadgita XVII.11 (Pudja, 2003: 364) sebagai berikut:

\section{Aphalakanksibhir yajno \\ Widhidristo ya ijyate, \\ Yastawyam ewe 'ti manah \\ Samadhaya sa satwikah \\ Terjemahannya: \\ Yadnya menurut petunjuk kitab-kitab suci \\ Dilakukan oleh orang tanpa mengharap phala \\ Dan percaya sepenuhnya upacara ini \\ Sebagai tugas dan kewajiban adalah sattwika}

Berdasarkan jenisnya, yadnya digolongkan kedalam lima bagian besar yakni Dewa Yadnya (persembahan suci kepada Tuhan dan manifestasi-Nya), Pitra Yadnya (pengorbanan maupun persembahan suci kepada orangtua, leluhur), Rsi Yadnya pengorbanan maupun persembahan kepada pendeta, guru spiritual, orang suci, bhagavan), Manusa Yadnya (pengorbanan tulus ikhlas kepada sesama manusia maupun persembahan suci untuk memelihara kesejahteraan hidup manusia) dan Bhuta Yadnya (Yadnya untuk menetralisir kekuatan-kekuatan negatif yang disimbolkan oleh para bhuta). Dalam konteks ini, yadnya sebaiknya dimaknai secara filosofis praktis. Secara filosofis, yadnya adalah satu bentuk doa, persembahan, pengorbanan yang dilandasi ketulusan, pengabdian dan cinta kasih kepada semua aspek yang menunjang kehidupan manusia. Pada tataran praktik, yadnya tidak hanya dimaknai sebagai ritual, melainkan tindakan-tindakan nyata sesuai makna filosofis yadnya tersebut.

Linggih (2016: 235) pada sub bagian tulisannya tentang nilai yadnya dalam cerita Ekalawya belum menyentuh substansi yadnya dalam konteks kisah ini melainkan masih menggambarkan yadnya secara umum. Sementara dalam tulisan ini, idealisme Ekalawya yang berkaitan dengan aspek Rsi Yadnya ini merupakan pengejawantahan dari pengorbanan dan persembahan kepada guru atas jasanya berupa ilmu pengetahuan yang telah diberikan. Bagi Ekalawya, ber-yadnya, berkorban kepada guru adalah sebuah kewajiban bagi seoarang sisya/siswa. Walaupun Drona tidak secara langsung memberikan/menurunkan ilmunya kepada Ekalawya, tetapi Drona telah dianggap, bahkan diyakini sebagai guru olehnya, maka sebagai bentuk terimakasih itu, seorang guru pantas menerima daksina dari siswanya. Terlepas dari maksud Drona adalah untuk melemahkan kemampuan Ekalawya dalam memanah, dengan tujuan menepati janjinya kepada Arjuna, akan tetapi itu adalah bentuk yadnya yang memang harus dilakukan oleh seorang sisya/siswa yang memiliki hati nurani. Namun memang bentuk persembahan yang diminta oleh Drona tidak lumrah, yakni ibu jari tangan kanan Ekalawya. Rasa terimakasih yang begitu besar, dan penghormatannya kepada sang guru lah yang mendorong Ekalawya bersedia secara sukarela menyerahkan ibu jarinya, dan tetap bersujud serta memberi hormat pada gurunya.

Ada persamaan dalam hal prinsip-prinsip yang dilakukan Ekalawya dengan peserta didik saat ini. Era tatanan baru ini seakan mendobrak kebiasaan-kebiasaan lama terkhusus dalam bidang pendidikan ke arah digitalisasi pembelajaran. Model maupun metode konvensional secara otomatis bergeser menuju paradigma yang mengarah pada kesesuaian dengan realitas abad 21. Penguasaan teknologi informasi, kemampuan berpikir kritis, 
berkomunikasi yang baik dan terampil, kemampuan dalam berkolaborasi, membangun kreatifitas, penguatan pendidikan karakter menjadi agenda pembaharuan bidang pendidikan yang harus dioptimalkan. Dibalik semua itu, ada peluang dan tantangan yang dihadapi, karena untuk melakukan perubahan besar dan pencapaian yang maksimal, diperlukan perjuangan yang berat pula. Sejalan dengan hal tersebut, Segara (2016: 253) menyatakan bahwa karakter yang kuat merupakan modal sosial dalam menjalani kehidupan, layaknya Karna dan Ekalawya. Idealisme yang dimiliki Ekalawya tersebut jika dikaitkan dengan pendidikan di era tatanan baru ini merupakan sebuah refleksi tentang kondisi yang dialami siswa/ peserta didik yang dapat diuraikan sebagai berikut:

a. Interaksi guru-peserta didik terbatas

Pembelajaran secara daring ini bisa jadi merupakan hal baru bagi sebagian besar siswa di tanah air, walaupun beberapa sekolah sudah menggunakan format blended learning sebelumnya. Belajar dari rumah menggunakan media-media digital awalnya menemui banyak kendala teknis, ketika ada guru yang belum terbiasa menggunakan media-media belajar tersebut, ataupun dari sisi peserta didik maupun orangtua yang juga tidak terbiasa menggunakannya untuk kepentingan pembelajaran. Namun setelah berjalan beberapa bulan, menjadi terbiasa, akan tetapi muncul kendala lainnya yaitu keterbatasan perangkat dan biaya yang dimiliki peserta didik untuk mengikuti pembelajaran daring ini. Azzahra (2020: 1) merinci beberapa pesan utama dalam kajiannya terhadap hambatan pembelajaran jarak jauh di Indonesia pada masa pandemi Covid-19 diantaranya sekitar 45 juta peserta didik tidak bisa melanjutkan kegiatan pembelajaran di sekolah. Menurutnya pemerintah dalam hal ini perlu mengambil kebijakan terkait perbedaan karakterisitik wilayah di Indonesia yang memiliki kemampuan berbeda dalam beradaptasi dengan format belajar daring ini. Selain itu, peran pemerintah daerah diperlukan dalam membantu sekolah-sekolah di daerahnya, lalu pentingnya peningkatan kapasitas kepala sekolah dalam hal otonomi dan peningkatan kualitas penguasaan hal-hal teknis maupun non teknis dari kalangan guru. Kerjasama pemerintah dengan pihak swasta dalam hal penyediaan jasa telekomunikasi (kuota gratis untuk guru dan siswa) juga penting diupayakan. Pemerintah melalui Kementerian Pendidikan dan Kebudayaan telah mengupayakan bantuan dengan menggelontorkan dana senilai Rp. 7,2 Triliun sebagai bentuk subsidi kuota internet bagi siswa, guru, mahasiswa dan dosen selama empat bulan (https://setkab.go.id/kemendikbud-resmikan-kebijakan-bantuan-kuota-data-internet-2020/).

Sejalan dengan hal itu, hambatan lainnya menurut Anugrahana (2020: 286) diantaranya beberapa siswa tidak memiliki handphone, tidak adanya koneksi internet, handphone dibawa orangtua untuk bekerja, orangtua tidak paham teknologi, terlambatnya penerimaan informasi oleh siswa karena ketiadaan fasilitas handphone dan kuota internet.

Selain kendala teknis, fenomena yang paling menonjol adalah terbatasnya interaksi antara guru dengan peserta didik. Sebelum adanya kebijakan belajar dari rumah, guru dan peserta didik selalu bertatap muka dalam pembelajaran di dalam kelas, dan guru secara leluasa menyampaikan materi serta penugasan kepada peserta didik. Begitu memasuki pembelajaran daring ini, guru terkadang hanya memberikan materi melalui video pembelajaran yang sangat singkat, hal ini karena terbatasnya kemampuan media digital dalam mengirimkan pesan video. Meskipun ada platform lain yang memfasilitasi hal itu, namun tidak semua guru menggunakan media tersebut, dan tidak semua peserta didik maupun orangtua mampu mengaksesnya, karena keterbatasan biaya. Ini tentu menyulitkan, baik bagi guru maupun peserta didik, tetapi guru yang kreatif akan berusaha menyampaikan materi dengan menggunakan media-media yang cost friendly (ramah biaya), menarik dan efektif. Tentu dengan adanya subsidi kuota internet yang telah diberikan oleh pemerintah diharapkan dapat menunjang pembelajaran daring ini.

Kondisi keterbatasan yang dialami peserta didik, termasuk keterbatasan sarana prasarana maupun interaksi dengan gurunya sebagai refleksi dari keadaan yang memaksa pembelajaran daring ini dilakukan. Meminjam hasil penelitian Megawanti (2020: 77) yang menyatakan bahwa hampir seluruh respondennya lebih senang belajar di sekolah karena 
memerlukan penjelasan langsung dari guru yang tidak bisa didapatkan dari pembelajaran daring, ini menandakan kehadiran guru sangat diperlukan dalam pembelajaran. Begitu juga dengan hasil penelitian Ahnusudar (55) yang seluruh respondennya memilih pembelajaran tatap muka daripada secara daring, dan ini juga menguatkan bahwa interaksi pendidik dan peserta didik tidak dapat digantikan oleh aplikasi. Sama halnya dengan Ekalawya yang memiliki keterbatasan berguru dengan Drona akibat ditolak sebagai muridnya, sehingga harus membuat patung Drona sebagai simbol gurunya dan Ekalawaya belajar dengan media patung tersebut. Sementara dalam kondisi saat ini peserta didik dilarang bertemu dengan guru atau temannya karena kebijakan pemerintah untuk mencegah penularan covid-19. Walaupun demikian, keterbatasan itu tidak sampai menghentikan kegiatan pembelajaran, tetapi tetap berlangsung dengan merubah formatnya menjadi belajar dari rumah secara daring dengan menggunakan media "patung" digital.

b. Kerja keras dalam penyelesaian beban tugas dari guru

Format pembelajaran jarak jauh atau daring memerlukan dukungan, tidak hanya perangkat maupun prasarana yang memadai, namun juga kesiapan penggunanya, baik guru maupun peserta didik. Masalah yang kerap muncul selama kegiatan belajar daring ini diantaranya ketidakselarasan antara model, metode dan media pembelajaran yang digunakan. Hal ini berdampak pada tercapai atau tidaknya tujuan pembelajaran. Selain itu keluhan juga seringkali datang dari siswa dan orangtua. Meminjam pernyataan Padli dan Rusdi (2020: 2) keluhan pada pihak siswa yakni adanya beban tugas berlebih yang diberikan oleh guru, tanpa adanya feedback serta referensi yang bisa dijadikan pedoman dalam mengerjakan evaluasi pembelajaran. Guru hanya menginstruksikan siswa untuk mengerjakan tugas pada media belajar yang digunakan, tanpa adanya penjelasan lebih lanjut. Demikian pula dari sisi guru yang mengeluhkan ketidaksesuaian rencana pembelajaran sebelumnya dengan realitas saat ini. Meskipun pada awal semester ganjil ini, guru sudah membenahi metode yang digunakan, namun terkadang tugas yang diberikan tidak terukur dengan baik, sehingga membebani siswa dan orangtua yang mendampingi. Ketika pembelajaran luring bertatap muka di sekolah, tugas yang diberikan tidak sepadat dalam pembelajaran daring ini. Pembelajaran dengan format luring/ bertatap muka di sekolah memberikan tingkat pemahaman yang relatif lebih baik pada siswa, ini sejalan dengan temuan Padli dan Rusdi yang mengemukakan bahwa dari 106 responden (siswa SMP dan SMA atau sederajat pada beberapa Kota/Kabupaten di Provinsi Sulawesi Selatan), 90\% menyatakan lebih berminat kelas langsung (tatap muka di sekolah) dibandingkan pembelajaran online, karena dapat bertemu langsung dengan teman-temannya dan gurunya, serta lebih mudah dalam memahami materi.

Pada hakekatnya, tugas dan kewajiban peserta didik memang belajar, dan penugasan adalah bagian dari kegiatan pembelajaran serta merupakan suatu keniscayaan. Di satu sisi seorang guru tidak hanya dituntut cakap dalam menyampaikan materi kepada peserta didik, tetapi mampu mengukur kemampuan siswa dalam mengerjakan tugas yang diberikan. Sementara seorang peserta didik hendaknya memiliki prinsip kerja keras dan pantang menyerah dalam mengerjakan tugas-tugas yang diberikan. Belajar dari rumah bukan lantas dijadikan ajang untuk bersantai dan bermain saja ketika jam pelajaran telah usai, tetapi waktu tersebut dimanfaatkan untuk mempelajari kembali materi telah disampaikan guru, mengerjakan dan menyelesaikan tugas yang diberikan dengan bersemangat, tidak mengeluh apalagi menuangkan keluhan di media sosial, tentu bukan hal yang elok. Lihat kembali kisah Ekalawya yang memiliki keterbatasan namun masih mampu mewujudkan cita-citanya menjadi seoarang pemanah. Ilmu pengetahuan tidak diperoleh dengan cara yang mudah, ada perjuangan, kerja keras dan semangat pantang menyerah untuk memilikinya. Seperti pesan yang disampaikan pada salah satu sloka dalam Canakya Nitisastra X.3 (Darmayasa, 2014: 94) berikut:

Sukarthi cetyajed-vidyam

Vidyarthi cetyajet-sukham

Sukharthinah kuto vodya 


\section{Kuto vidyarthinah sukham}

Terjemahannya:

Jika menginginkan kesenangan, buanglah jauh-jauh ilmu pengetahuan.

Jika menginginkan ilmu pengetahuan, tinggalkan kesenangan.

Oleh karena bagi orang yang menginginkan kesenangan indria, mana mungkin ada ilmu pengetahuan, dan sebaliknya bagi yang mengharapkan ilmu pengetahuan, mana mungkin ada kesenangan. Dengan memahami hal tersebut, peserta didik sepatutnya memacu diri, bersemangat, pantang menyerah, bekerja keras dan bersungguh-sungguh dalam mengerjakan setiap tugas yang diberikan, bukan melakukan hal lain yang tidak penting. Seperti kata Plato, akar dari pendidikan itu pahit, tetapi buahnya manis. Penolakan Ekalawya memang dirasa pahit dan mengecewakan, tetapi dengan kerja keras yang dilakukan, membawanya pada posisi pemanah terhebat kala itu.

c. Kemandirian, kedisiplinan dan kejujuran peserta didik

Bentuk pembelajaran daring secara implisit menumbuhkan dan menguatkan karakter pada peserta didik, diantaranya mandiri, disiplin, dan jujur. Mengutip pendapat Ambiyar (1247), kemandirian siswa dalam pembelajaran online ini nampak pada kemampuan siswa dalam mengelola waktu dan menggunakan beragam sumber belajar. Kemandirian dapat dilatih melalui penugasan maupun evaluasi. Peserta didik dituntut dapat mengerjakan tugas secara mandiri, menemukan referensi terkait tugas, menyusun skala prioritas hingga menyelesaikan tugas dan mengunggah tugas pada media yang telah ditentukan. Sejalan dengan pendapat Pujiasih (2020: 47) bahwa pembelajaran online menuntut siswa untuk mandiri dan kreatif dalam memanfaatkan media belajar, baik dari internet maupun yang diberikan oleh guru. kedisiplinan dalam mengerjakan tugas, mengatur waktu belajar dan bermain, mengumpulkan tugas tepat waktu dan sesuai petunjuk pengerjaan. Selanjutnya kejujuran dilatih ketika peserta didik menjawab soal kuis atau ujian tengah semester dalam format daring. Berkaitan dengan penilaian sikap, terutama sikap sosial, sulit mengukurnya jika pembelajaran dilakukan dalam format daring, tetapi bisa diantisipasi dengan kerjasama antara guru dan orangtua untuk memberikan penilaian secara objektif kepada putra-putrinya melalui media google form. Akan tetapi ada kalanya orangtua justru membantu putra-putrinya mengerjakan soal kuis atau ujian yang diberikan sehingga nilainya tidak murni dan kejujuran tidak bisa diberikan nilai secara objektif. Guru tidak bisa mengetahui tingkat kejujuran siswa dalam menjawab semua soal, karena kontrol yang terbatas dari guru. Sedangkan orangtua yang berorientasi pada nilai kuantitatif akan mengusahakan nilai terbaik untuk putra-putrinya, dengan cara dibantu, dan ini bentuk pembiasaan yang tidak baik. Senada dengan pernyataan Srigati (2021: 5) bahwa kejujuran siswa dalam mengerjakan ujian scara daring berkurang bahkan memicu siswa melakukan plagiarism. Kesadaran orangtua dan siswa sendiri juga harus dibangun untuk mengoptimalkan misi penguatan karakter dalam pembelajaran daring ini.

Berkaca dari kisah Ekalawya, kedisiplinan, kemandirian dan kejujuran sudah terlihat sejak penolakan yang diterima, ketaatan Ekalawya pada aturan sosial, tentang Varna yang harus dipatuhi, walaupun ada kekecewaan dalam hatinya. Keputusannya untuk membuat patung Drona sebagai simbol gurunya, lalu berlatih secara mandiri atau otodidak menjadikannya pemanah yang hebat menunjukkan kemandiriannya dalam mewujudkan citacitanya, mampu menyelesaikan masalah yang dihadapi tanpa beban emosional. Begitu pula kejujuranya ketika ditanya guru yang telah mengajarinya dan bagaimana caranya mendapat ilmu memanah, Ekalawya mengatakan apa adanya, walaupun konsekuensinya adalah menyerahkan ibu jari tangan kanannya kepada Drona sebagai daksina.

d. Rasa hormat yang harus tetap dijaga

Karakter siswa saat ini memang menunjukkan kecenderungan penurunan kualitas, diantaranya kurangnya rasa hormat kepada guru. Ini mungkin dikarenakan guru kini dilarang melakukan kekerasan secara fisik dan verbal terhadap siswa apapun alasannya. Memarahi apalagi sampai memukul siswa yang nakal seakan menjadi hal tabu yang pantang dilakukan 
guru, karena jika itu dilakukan, justru anak tersebut mengadu kepada orangtua, dan guru akan didatangi orangtua menuntut pertanggungjawaban atas perlakuan terhadap anaknya. Walaupun tidak semua orangtua berprilaku demikian, tetapi tidak sedikit kasus kekerasan yang dilakukan siswa atau orangtua siswa kepada guru. Fenomena ini menggambarkan belum optimalnya internalisasi nilai-nilai etika dan moral di lingkungan keluarga maupun sekolah, jika tidak mau disebut gagalnya sistem pendidikan. Pendidikan nasional diarahkan untuk mewujudkan generasi yang berbudi pekerti luhur, cerdas, sehat jasmani rohani, mandiri dan bertanggungjawab terhadap diri sendiri, bangsa dan Negara, singkatnya memiliki karakter yang mulia. Tujuan tersebut sulit diwujudkan jika tidak adanya peran serta keluarga dan masyarakat. Pendidikan pertama dimulai di lingkungan keluarga, untuk itu, orangtua menanamkan nilainilai moral pada anak sejak dini, sehingga ketika memasuki masa pendidikan di sekolah, bekal afektif itu sudah ada.

Sikap hormat pada guru bukan sebuah pilihan, tetapi keharusan bagi seorang siswa, namun kenyataan kini berbeda. Pembelajaran era tatanan baru ini tidak hanya merubah sistem pembelajaran tetapi mempengaruhi tingkat kepatuhan, ketaatan, termasuk kesantunan dan rasa hormat kepada guru. Siswa yang diberikan tugas oleh gurunya dan tidak mau atau tidak mampu mengerjakannya, akan meminta bantuan orangtuanya. Saat anaknya sulit memahami penjelasan orangtuanya, anak sering menjadi sasaran kemarahan dan pada akhirnya guru yang disalahkan karena membebani siswa dan orangtua dengan tugas yang banyak dan sulit. Beban tugas dari guru seharusnya tidak melunturkan kesantunan, seperti yang dilakukan Ekalawya yang tidak menaruh dendam atas perlakuan Drona terhadap dirinya.Rasa hormatnya tidak pernah surut, sekalipun ditolak sebagai muridnya, dan ditagih sebuah persembahan yang berat, Ekalawya tetap sujud dan bhakti kepada Drona dalam keadaan apapun. Acarya devo bhava, guru bhakti.

\section{Kesimpulan}

Pembelajaran di era tatanan baru hendaknya juga dipandang sebagai sebuah peluang bagi kemajuan pendidikan, tidak semata-mata perubahan yang hanya menimbulkan berbagai polemik. Penguasaan TIK, kemandirian, critical thinking, disiplin, kerja keras merupakan beberapa bentuk kecakapan abad 21 dan penguatan karakter yang dapat dikembangkan melalui pembelajaran daring. Seorang peserta didik harus memiliki idealisme untuk kemajuan pribadinya, seperti halnya seorang Ekalawya pada jamannya, dengan segala keterbatasan yang dimiliki, tidak menghalangi kemauannya yang kuat. Berkat kedisiplinan, kemandirian, keteguhan, kerja keras dan sikap santunnya mampu membawanya pada pencapaian sebagai pemanah yang hebat. Begitu juga siswa yang menjadi bagian dari era tatanan baru, dengan keterbatasan yang dihadapi, seharusnya tidak menguarangi semangat dalam menuntut ilmu dan menggapai cita-cita.

\section{Daftar Pustaka}

Ahmad, J. (2018). Desain penelitian analisis isi (Content analysis). Research Gate, 5, 1-20.

Ambiyar, A., Aziz, I., \& Melisa, M. (2020). Perbedaan Kemandirian Belajar Siswa Pada Masa Pandemi di SMAN 1 Lembah Melintang dan SMAN 1 Lembah Gumanti. Jurnal Cendekia: Jurnal Pendidikan Matematika, 4(2), 1246-1258.

Anhusadar, L. (2020). Persepsi mahasiswa PIAUD terhadap kuliah online di masa pandemi Covid 19. KINDERGARTEN: Journal of Islamic Early Childhood Education, 3(1), 4458.

Anugrahana, A. (2020). Hambatan, Solusi dan Harapan: Pembelajaran Daring Selama Masa Pandemi Covid-19 Oleh Guru Sekolah Dasar. Scholaria: Jurnal Pendidikan dan Kebudayaan, 10(3), 282-289.

Aritonang, D. R. (2018). Analisis Pendekatan Resepsi Sastra Terhadap Novel "Chairil Tanjung Si Anak Singkong. LINGUISTIK: Jurnal Bahasa dan Sastra, 3(1), 62-73. 
Azzahra, N. F. (2020). Mengkaji Hambatan Pembelajaran Jarak Jauh di Indonesia di Masa Pandemi Covid-19.

Darmayasa, I. M. (2014). Canakya Niti Sastra. Surabaya: Paramita.

Daryanto, d. S. (2013). Implementasi Pendidikan Karakter di Sekolah. Yogyakarta: Gava Media.

Fiteriani, I. (2015). Membudayakan Iklim Semangat Belajar Pada Siswa Sekolah Dasar. TERAMPIL: Jurnal Pendidikan dan Pembelajaran Dasar, 2(1), 115-25.

I Nyoman Kajeng, d. (1997). Sarasamuccaya dengan Teks Bahasa Sanskerta dan Jawa Kuna. Surabaya: Paramita.

Juliani, N. M. (2020). Sistem Belajar Otodidak Ekalawya Dalam Adi Parwa. WIDYALAYA: Jurnal Ilmu Pendidikan, 1(2), 185-192.

Kementerian Pendidikan dan Kebudayaan Republik Indonesia. Konsep dan Pedoman Penguatan Pendidikan Karakter Tingkat Sekolah Dasar dan Sekolah Menengah Pertama

Kementerian Pendidikan dan Kebudayaan (2017, 17 Juli). Penguatan Pendidikan Karakter Jadi Pintu Masuk Pembenahan Pendidikan Nasional. Diakses pada 1 November 2020, dari https://www.kemdikbud.go.id/main/blog/2017/07/penguatan-pendidikan-karakterjadi-pintu-masuk-pembenahan-pendidikan-nasional.

Lilawati, A. (2020). Peran Orang Tua dalam Mendukung Kegiatan Pembelajaran di Rumah pada Masa Pandemi. Jurnal Obsesi: Jurnal Pendidikan Anak Usia Dini, 5(1), 549-558.

LINGGIH, I. N. (2016). PERAN CERITRA EKALAWYA SEORANG NISADA DALAM MEMBENTUK KARAKATER ANAK SEKOLAH DASAR. Prosiding Nasional.

Megawanti, P. (2020). Persepsi Peserta Didik Terhadap PJJ pada Masa Pandemi Covid 19. Jurnal Faktor UNINDRA, 7(2), 75-82.

Mustari, M. (2014). Nilai Karakter Refleksi untuk Pendidikan. Jakarta: Raja Grafindo Persada. Netra, A. A. (2009). Tuntunan Dasar Agama Hindu. Denpasar : Widya Dharma.

Padli, F., \& Rusdi, R. (2020). RESPON SISWA DALAM PEMBELAJARAN ONLINE SELAMA PANDEMI. Social Landscape Journal, 1(3), 1-7.

Pudja, G. (2003). Bhagawad Gita (Pancama Weda). Jakarta: Pustaka Mitra Jaya.

Pujiasih, E. (2020). Membangun generasi emas dengan variasi pembelajaran online di masa pandemi covid-19. Ideguru: Jurnal Karya Ilmiah Guru, 5(1), 42-48.

Ricoeur, P. (2006). Hermeneutika Ilmu Sosial. Yogyakarta: Kreasi Wacana.

Riyanto, H. (2012). Paradigma Baru Pembelajaran Sebagai Referensi bagi Pendidik dalam Implementasi Pembelajaran yang Efektif dan Berkualitas. Jakarta: Kencana.

S.Radhakrishnan. (2008). Upanisad Upanisad Utama. Surabaya: Paramita.

SEGARA, I. N. Y. (2016). Pendidikan Karakter Dan Kebutuhan Pasraman Formal. Prosiding Nasional.

Sekretariat Kabinet Republik Indonesia (2020, 25 September). Kemendikbud Resmikan Kebijakan Bantuan Kuota Data Internet 2020. Diakses pada 1 November 2020, dari https://setkab.go.id/kemendikbud-resmikan-kebijakan-bantuan-kuota-data-internet2020/

Srigati, D. (2021). Membentuk Karakter Siswa di Masa Pandemi Covid-19.

Suarjaya, I. W. (2018). MODEL PEMBELAJARAN HINDU DALAM ADI PARWA. Bawi Ayah: Jurnal Pendidikan Agama Dan Budaya Hindu, 9(1), 49-56.

Subramaniam, K. (2003). Mahabharata. Surabaya: Paramita.

Sudharta, T. R. (2003). Slokantara. Surabaya: Paramita.

Suprapti, N. K. W. (2020). Menumbuhkan Kemandirian Belajar Siswa Kelas VII 1 SMP Negeri 2 Amlapura di Tengah Pandemi Covid-19 dengan Spirit Ekalawya. Cetta: Jurnal Ilmu Pendidikan, 3(3r). 
Surat Edaran Menteri Pendidikan dan Kebudayaan RI Nomor 4 Tahun 2020 tentang Pelaksanaan Kebijakan Pendidikan dalam Masa Darurat Penyebaran Corona Virus Disease (Covid-19),

Tangkas, M. R. U. (2020). Ekalawya; Bukti Keberhasilan Mutu Pendidikan (Catatan Teks Adi Parwa). PINTU: Jurnal Penjaminan Mutu, 1(1).

Titib, I. M. (2003.). Menumbuhkembangkan Pendidikan Budhi Pekerti pada Anak (Perspektif Hindu). Jakarta: Ganeca Exact. 